\title{
Increased Gene Expression for VEGF and the VEGF Receptors KDR/FIk and Flt in Lungs Exposed to Acute or to Chronic Hypoxia

\author{
Modulation of Gene Expression by Nitric Oxide
}

Rubin M. Tuder, Barbara E. Flook, and Norbert F. Voelkel

Division of Pulmonary Sciences and Critical Care Medicine, Pulmonary Hypertension Center and Department of Pathology, University

of Colorado, Health Sciences Center, Denver, Colorado 80262

\begin{abstract}
Endothelial cells constitute an essential integrator of factors that affect blood vessel remodeling induced by chronic hypoxia. We hypothesized that vascular endothelial growth factor (VEGF) may participate in the lung response to acute and to chronic hypoxia. We found that ex vivo perfusion of isolated lungs under hypoxic conditions (when compared with normoxia) caused an increase in lung tissue mRNA of VEGF and of the VEGF receptors KDR/Flk and Flt. Chronic hypobaric hypoxia also increased lung tissue mRNA levels of VEGF, KDR/Flk, and Flt and the amount of VEGF protein. In situ hybridization studies demonstrated increased VEGF and KDR/flk hybridization signals in lungs from chronically hypoxic rats. Since endotoxin treatment of rats decreased lung VEGF mRNA, we postulated that nitric oxide (NO) or an NO-related metabolite might be involved in lung VEGF gene expression. Indeed, sodium nitroprusside, a NO donor, decreased and L-NAME ( $N$-nitro-L-arginine methyl ester), an inhibitor of NO-synthesis, increased both VEGF and VEGF receptor transcripts. We conclude that VEGF in the isolated perfused lung acts as an early gene in response to hypoxia and that lung VEGF and VEGF receptor mRNA levels are influenced by hypoxia and NOdependent mechanisms. (J. Clin. Invest. 1995. 95:17981807.) Key words: vascular endothelial growth factor (VEGF) - VEGF receptors - acute and chronic hypoxia • pulmonary hypertension • nitric oxide
\end{abstract}

\section{Introduction}

Chronic hypoxia represents one of the stimuli that accounts for pulmonary vascular remodeling in chronic lung diseases. This remodeling process involves hypertrophy of the precapillary vascular smooth muscle cells, proliferation of endothelial cells and pericytes, and enhanced vascular permeability (1-3). Since hypoxia per se does not cause hyperplasia of cultured pulmonary vascular smooth muscle cells, it is reasonable to assume that, in vivo, hypoxia and vascular cell growth factors act synergis-

Address correspondence to Norbert F. Voelkel, M.D., University of Colorado Health Sciences Center, Box C 272, 4200 E. Ninth Ave., Denver, CO 80262. Phone: 303-270-4211; FAX: 303-270-5632.

Received for publication 12 August 1994 and in revised form 13 October 1994.

J. Clin. Invest.

(c) The American Society for Clinical Investigation, Inc.

0021-9738/95/04/1798/10 \$2.00

Volume 95, April 1995, 1798-1807 tically on growth and differentiation of pulmonary vascular cells (4).

Endothelial cells have a central role in integrating signals that may affect pulmonary vessel structure and function. Increased shear stress, as seen during hypoxic vasoconstriction, results in endothelial cell expression of vascular cell growth factors, such as platelet derived growth factor (PDGF) or transforming growth factor (TGF- $\beta$ ) or proinflammatory molecules like ICAM-1 (5).

Vascular endothelial cell growth factor (VEGF), ${ }^{1}$ a peptide mitogen specific for endothelial cells (6-14), is abundantly expressed in lung tissue, including pneumocytes and activated alveolar macrophages $(8,10)$. Although the function of VEGF in normal tissue remains unknown, brain tumor cells, cancer cells, muscle myoblasts and fibroblasts upregulate VEGF expression under conditions of hypoxia (15). Indeed, VEGF represents one of the main endothelial cell growth factors produced by malignant cells, and may be involved in endothelial cell proliferation observed in pulmonary vascular remodeling.

VEGF binds to two highly homologous tyrosine kinase receptors expressed exclusively by endothelial cells: the tyrosine kinase receptor KDR (or the murine homologue fetal liver kinase-flk) (16-18), and the fms-like tyrosine kinase receptor Flt $(19,20)$. Although VEGF binding to Flt triggers receptor autophosphorylation and $\mathrm{Ca}^{2+}$ influx, Flt activation does not suffice to cause endothelial cell proliferation in both in vitro as well as in vivo models of tumor-mediated angiogenesis (21). On the other hand, transfection with KDR/Flk causes cell proliferation, chemotaxis and actin rearrangement upon VEGF exposure of porcine endothelial cells (21). Furthermore, mutant forms of Flk can abrogate VEGF induced signal transduction in vitro and can also reduce blood vessel proliferation in in vivo models of brain cancers (22). These studies suggest that the biologic function of VEGF in disease states, including hypoxic pulmonary hypertension, may rely on increased amounts of VEGF protein as well as increased VEGF receptor number and affinity.

In the present study, we pursue the hypothesis that VEGF mRNA and protein and the VEGF receptors Flt and KDR/Flk mRNA are increased in lungs subjected to acute or to chronic hypoxia. To compare the effects of acute hypoxia with an agent that also alters pulmonary vascular tone, we also evaluated the acute effect of endotoxin on VEGF gene expression. Endotoxin inhibits acute hypoxic vasoconstriction and may alter growth factor expression in the hypertensive lungs. Since endotoxin causes large increases in nitric oxide (NO) production, we also

1. Abbreviations used in this paper: GAPDH, glyceraldehyde phosphate dehydrogenase; NO, nitric oxide; SNP, sodium-nitroprusside; VEGF, vascular endothelial growth factor. 
tested the effect of the NO-donor sodium-nitroprusside (SNP) on lung tissue VEGF and VEGF receptor gene expression. Our data in the aggregate indicate that both VEGF and the VEGF receptors in the lung are regulated by acute and chronic hypoxia, and that NO modifies the VEGF and VEGF receptor gene expression in the lung during hypoxic and normoxic conditions.

\section{Methods}

\section{Chronic exposure to hypoxia}

Adult male Sprague-Dawley rats were purchased from a commercial vendor and kept for $7 \mathrm{~d}$ in the Animal Care Facility of the University of Colorado Health Sciences Center. Thereafter, the rats were weighed and randomized to a control (Denver altitude, $5600 \mathrm{ft}$ ) and a chronic hypoxia $(16,000 \mathrm{ft}$ simulated high altitude) group. The rats weighed 300-330 grams and were divided into different groups: control, and various periods of hypoxic exposure ranging from 1 to $32 \mathrm{~d}$. Control $(n=3)$ and hypoxia-exposed rats $(n=15)$ had free access to food and water and were subjected to the same day and night light cycle. After conclusion of the predetermined hypoxia exposure, the animals were removed from the hypobaric chamber and anesthetized with $100 \mathrm{mg} /$ $\mathrm{kg}$ pentobarbital (Nembutal). Then a midline thoracotomy was performed, and the lungs were quickly isolated and excised. The left main bronchus was cross clamped and the right lung was immediately instilled with melted agarose and suspended in a phosphate buffer and stored at $4^{\circ} \mathrm{C}$ overnight (23); these lungs were then frozen, sectioned and prepared for in situ hybridization. The left lung was flash frozen in liquid nitrogen and stored at $-72^{\circ} \mathrm{C}$ until used for RNA extraction or the VEGF ELISA assay.

\section{Acute exposure to hypoxia}

Lungs were isolated from adult rats and perfused at constant flow $(0.03$ $\mathrm{ml} / \mathrm{gBW} / \mathrm{min}$ ) with a cell-free physiological salt solution and the perfusion pressure was measured continually as previously described (24). The lungs were kept moist in a plexiglass chamber at $37^{\circ} \mathrm{C}$; some of the lungs were ventilated with a room air gas mixture $\left(21 \% \mathrm{O}_{2}\right.$, and $5 \% \mathrm{CO}_{2}$ and $74 \% \mathrm{~N}_{2}$ ), other lungs were ventilated with a "hypoxic" gas mixture $\left(0 \% \mathrm{O}_{2}, 5 \% \mathrm{CO}_{2}\right.$ balance $\left.\mathrm{N}_{2}\right)$. This mode of ventilation results in a lung effluent $\mathrm{PO}_{2}$ of $30-35 \mathrm{mmHg}$. After $2 \mathrm{~h}$ of perfusion and ventilation the lungs were rapidly frozen in liquid nitrogen and stored at $-72^{\circ} \mathrm{C}$ until the time of RNA extraction.

\section{Endotoxin treatment}

12 rats received i.p. injection of S. enteritidis endotoxin (Sigma Chemical Co, St. Louis, MO; $2 \mathrm{mg} / \mathrm{kg}$ ). At $2,4,6$, or $12 \mathrm{~h}$ ( $n=3$ per time point) after endotoxin injection, the animals were sacrificed and the lungs were removed after thoracotomy and flash frozen until the time of RNA extraction. Three rats were injected with saline and served as controls.

\section{Nitric oxide studies}

Isolated lungs were perfused, under normoxic or hypoxic conditions, with a salt solution that contained either sodium nitroprusside at $10^{-4}$ $\mathrm{M}(n=4)$ or $\mathrm{N}^{\mathrm{G}}$-nitro-L-arginine methyl ester hydrochloride (L-NAME) at $10^{-4} \mathrm{M}(n=6)$ (Research Biochemicals International, Natick, MA). These studies were designed to test whether the increase or the decrease of lung nitric oxide (NO) production alters the expression of VEGF, $\mathrm{KDR} / \mathrm{Flk}$, and Flt by the lung tissue.

\section{Specific methods}

$\left.{ }^{3} H\right]$ thymidine labeling and autoradiography. Three rats had been exposed to chronic hypoxia for $28 \mathrm{~d}$, (three low altitude rat lungs served as controls); $1 \mu \mathrm{Ci}\left[{ }^{3} \mathrm{H}\right]$ thymidine (New England Nuclear, Boston, MA) was injected i.p. $1 \mathrm{~h}$ after this injection the animals received pentobarbital sodium $(100 \mathrm{mg} / \mathrm{kg})$ i.p., the lungs were excised, fixed in formalin, cut into sections, covered with photoemulsion and exposed for $4 \mathrm{wk}$ (2). The autoradiograms of the lung slices were inspected and photographed.
Northern blot studies. Total RNA was extracted from rat lung as described by Chomcynsky and Sacchi (25), fractionated by formaldehyde gel electrophoresis, and transferred onto Nylon membranes (Schleicher and Schell, Keene, NH). $20 \mu \mathrm{g}$ of total RNA were loaded per lane. The probes were prepared by random-priming labeling using $\left[{ }^{32} \mathrm{P}\right] \mathrm{dCTP}, 3000 \mathrm{Ci} / \mathrm{nMol}, 10 \mu \mathrm{Ci}, \mu \mathrm{l}$ (New England Nuclear). The mouse cDNA probe for $\beta$-actin and the mouse glyceraldehyde phosphate dehydrogenase (GAPDH) cDNA probes were a gift from Dr. J. Fisher (University of Colorado Health Sciences Center). The $28 \mathrm{~S}$ ribosomal cDNA was used for correction of RNA loading. The VEGF human cDNA probe $(687 \mathrm{bp}$ ) was provided by Irene Smith (Genentech, South San Francisco, CA). The human Flt cDNA was a 458-bp sac-1 fragment subcloned from the 3-9 cDNA (gift from Dr. Masabumi Shibuya) (19) into the $4 \mathrm{Z}$ plasmid (Promega, Milwaukee, WI). The KDR cDNA was provided by Dr. Bruce Terman $(16,17)$. Development of blots hybridized with the VEGF and VEGF receptor probes were performed for $\sim 8$ $h$ and $3 \mathrm{~d}$, respectively and subsequently quantified by phosphorimaging and scanning densitometry.

In situ hybridization, VEGF mRNA, KDR mRNA, Flt mRNA. Slides with sections of rat lungs were vacuum-dried for $2 \mathrm{~h}$ for attachment of sections to Superfrost slides (Fisher Scientific Co., Pittsburgh, PA), followed by treatment with $0.2 \mathrm{~N} \mathrm{HCl}$ for $20 \mathrm{~min}$, washing in depcPBS, proteinase $\mathrm{K}$ digestion at $10 \mu \mathrm{g} / \mathrm{ml}$ at $37^{\circ} \mathrm{C}$ for $20 \mathrm{~min}$, fixation in $4 \%$ paraformaldehyde for $5 \mathrm{~min}$, acetylation with ethanolamine with acetic-anhydrade (1:400 ratio) for 5 min. Blocking was performed in a premade solution containing 50\% formamide (Hybridization cocktail, Ameresco, Solon, $\mathrm{OH}$ ) for $2 \mathrm{~h}$ at room temperature.

VEGF transcripts were detected with the subclone rat-VEGF 2 (316 base pairs) cloned into a Bluescript KS + vector (Stratagene, La Jolla, CA), kindly provided by Drs. G. Breier and W. Risau (11). Sense and anti-sense cRNA probes for VEGF and KDR were labeled with digoxigenin-dUTP with the Genius IV kit as recommended by the manufacturer (Boehringer Mannheim, Indianapolis, IN). The probes were quantified by dot blot analysis using known concentrations of digoxigenin-labeled plasmid DNA as standard. The efficiency of labeling was further confirmed by agarose gel electrophoresis. Probes were used at a concentration of $25 \mathrm{ng} / \mathrm{section}$.

Hybridization was performed overnight at $42^{\circ} \mathrm{C}$. After extensive sequential washings in $2 \times, 1 \times$, and $0.5 \times$ SSC, the unhybridized probe was digested with ribonuclease (Promega, Madison, WI) in $0.5 \times$ SCC. The hybridization product was detected after incubation with a sheep anti-digoxigenin antibody (1/2000 dilution; Boehringer Mannheim, Indianapolis, IN) for $90 \mathrm{~min}$ followed by development in 4-tetrazolium chloride $4.5 \mu \mathrm{g} / \mathrm{ml}$ and $\mathrm{x}$-phosphate $3.5 \mu \mathrm{l}$ for $4-12 \mathrm{~h}$.

ELISA for VEGF. Rat lungs ( $\sim \mathrm{g}$ of tissue/lung) were homogenized in lysis buffer $(0.1 \mathrm{M}$ sodium carbonate $\mathrm{pH} 9.6,0.1 \% \mathrm{NP}-40,1$ $\mu \mathrm{M}$ leupeptin, $1 \mathrm{mM}$ PMSF, and $10 \mu \mathrm{l} / \mathrm{ml}$ ethylenediaminetetraacetic acid from a saturated stock), followed by sonication (Fisher Sonic Desmembrator; Fischer Scientific). The homogenate was then cleared by centrifugation at $750 \mathrm{~g}$, at $4^{\circ} \mathrm{C}$ for $6 \mathrm{~min}$. The supernatant was stored at $-20^{\circ} \mathrm{C}$ until assayed for VEGF protein levels. The experimental samples and recombinant $V_{E G F_{165}}$ standards (R \& D Systems, Inc., Minneapolis, $\mathrm{MN}$ ) were diluted in Carbonate buffer and added in triplicate to Immulon IV 96-well plates (Dinatech, Chantilly, VA). The samples were incubated at $37^{\circ} \mathrm{C}$ for $8 \mathrm{~h}$. Standards consisted of 2-fold dilutions of rVEGF $_{165}$, starting at $25 \mathrm{ng} /$ well to $390 \mathrm{pg} /$ well. The samples were removed and the wells were briefly washed in washing buffer (PBS pH 7.4, $0.05 \%$ Tween 20). The wells were blocked with blocking buffer (washing buffer with $1 \% \mathrm{BSA}$ ) at $37^{\circ} \mathrm{C}$ for $4 \mathrm{~h}$. After two brief washes, $10 \mu \mathrm{l}$ of rabbit anti-VEGF antibody (kindly provided by Dr. Napoleone Ferrara, Genentech, CA) was added to each well for $1 \mathrm{~h}$ at $37^{\circ} \mathrm{C}$. After washing twice, goat anti-rabbit peroxidase (Tago Inc., Burlingame, CA) was added for $1 \mathrm{~h}$. $O$-phenylenediamine dihydrochloride was used as substrate and the optical density was determined at $490 \mathrm{~nm}$ on a Syva Microtrak spectrophotometer. The program Statview 512 was used to plot optical density averages. The concentration of VEGF in the experimental samples was calculated with a formula derived by linear regression analysis of values of optical densities obtained with standard con- 


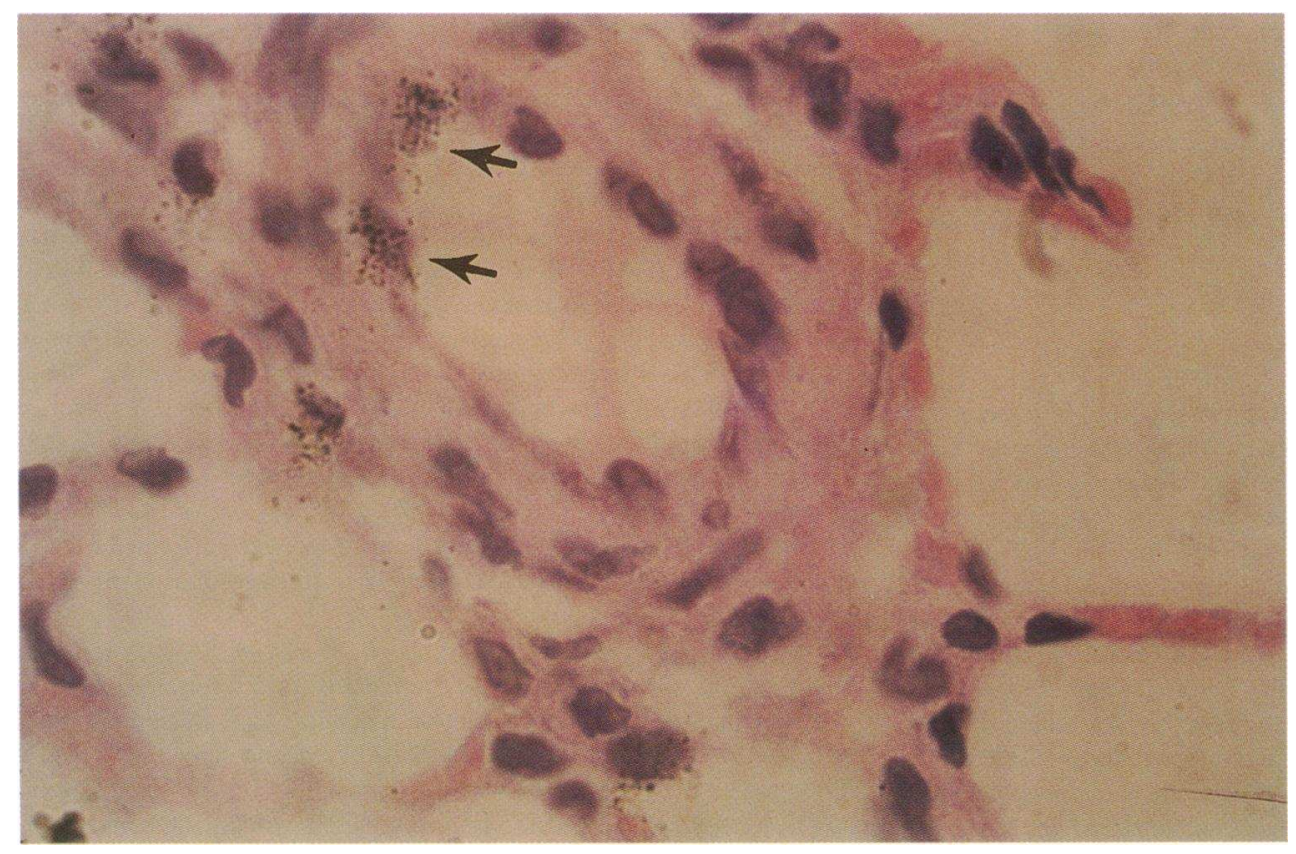

Figure 1. Rat lung $\left[{ }^{3} \mathrm{H}\right]$ thymidine autoradiogram. Hypertrophied small pulmonary artery from a rat exposed to hypobaric hypoxia for 4 wk. Two endothelial cells demonstrate $\left[{ }^{3} \mathrm{H}\right]$ thymidine incorporation (arrows). centrations of VEGF. The optical density curve for VEGF was linear in concentrations ranging between 390 and $6.25 \mathrm{pg} / 50 \mu \mathrm{l}$ (correlation coefficient $=.992$, see Fig. $4 B$ ).

\section{Results}

\section{In vivo studies}

\section{CHRONIC HYPOXIA}

$\left[{ }^{3} H\right]$ Thymidine autoradiography. To determine which of the vascular cell types (endothelium, smooth muscle cells or fibroblasts) undergo proliferation during hypoxia-induced lung vascular remodeling, sections of rat lung from animals exposed for $28 \mathrm{~d}$ to hypobaric pressure/hypoxia were inspected for $\left[{ }^{3} \mathrm{H}\right]$ thymidine labeling and autoradiography. The remodeled, muscularized arteries demonstrated multiple endothelial cells with ${ }^{3} \mathrm{H}$-incorporation consistent with endothelial cell proliferation (Fig. 1), while control lung vessels were characterized by rare cells with $\left[{ }^{3} \mathrm{H}\right]$ thymidine uptake. These results agreed with our earlier studies where differences of ${ }^{3} \mathrm{H}$-incorporation by pulmonary vascular cells under hypoxic conditions had been more precisely quantified (2).

$V E G F$ $m R N A$ and VEGF protein. VEGF mRNA was abundantly present in control lungs, as described in prior studies (10). At 28-32 days of hypoxic exposure, there was a two- to threefold increase in lung VEGF mRNA over controls. (Fig. 2). We recognized that the levels of transcripts for the so-called housekeeping genes $\beta$-actin and GAPDH varied during hypoxia and thus could not be used for densitometric quantification of mRNA from chronically hypoxic lungs. This variability of the GAPDH gene expression in conditions of hypoxia has recently been recognized by others $(26,27)$. Since the ribosomal RNA (rRNA) proved to be unchanged by hypoxia or hypobaric exposure, we elected to use $28 \mathrm{~S}$ rRNA as a reference. (Fig. 2).

Comparison of normoxic and hypoxic lung tissue processed by in situ hybridization technique, using the VEGF antisense probe labeled with digoxigenin, showed an increase in the hybridization signal in alveolar, intraalveolar and bronchio-alveo- lar cells when compared with control lungs. The signal however was mostly concentrated in epithelial alveolar cells in both the experimental and the control group of animals. (Fig. 3). VEGF protein measured in lung homogenates was likewise increased from day 3 up to day 32 of hypoxic exposure when compared with lungs of control rats (Fig. 4).

$V E G F$ receptor, KDR/Flk, and Flt mRNA. The VEGF function as a mitogen and as a permeability factor for endothelial cells relies on its interaction with tyrosine-kinase receptors. Northern blot technique and in situ hybridization were applied to assess changes induced by chronic hypoxia in lung tissue expression of VEGF receptor transcripts. Both KDR/Flk and Flt mRNA increased with prolonged (7-32 d) exposure to hypobaric hypoxia (Fig. 3). The increase of VEGF receptor expression by day 7 of hypoxia coincided with the first clear histological evidence of vascular remodeling as described in prior studies (28). It was apparent that, by in situ hybridization, the KDR/ Flk and Flt gene expression was concentrated in the pre-capillary vessels and in intraseptal cells throughout the period of the chronic hypoxia (Fig. 5). Alveolar macrophages, which did not stain in sections from control lungs, exhibited a weak hybridization signal for KDR/Flk transcripts in specimens from chronically hypoxic lungs.

Effect of endotoxin on VEGF transcripts. To put the effect of acute hypoxia in perspective, we examined the effect of a single intraperitoneal endotoxin injection on lung VEGF mRNA and found a time-dependent decrease in the abundance of VEGF transcripts in lungs from endotoxin-injected rats (Fig. 6).

\section{Ex vivo studies}

Acute hypoxia. To examine whether acute hypoxia of the isolated lung preparation (under constant flow and pressure conditions) affects VEGF and VEGF receptor gene expression, we compared lungs perfused with cell-free salt solutions which were ventilated with room air $\left(21 \% \mathrm{O}_{2}\right)$ with lungs ventilated with $0 \%$ oxygen. Lungs ventilated with $0 \%$ oxygen for $2 \mathrm{~h}$ showed an increase in tissue VEGF mRNA and also in the 


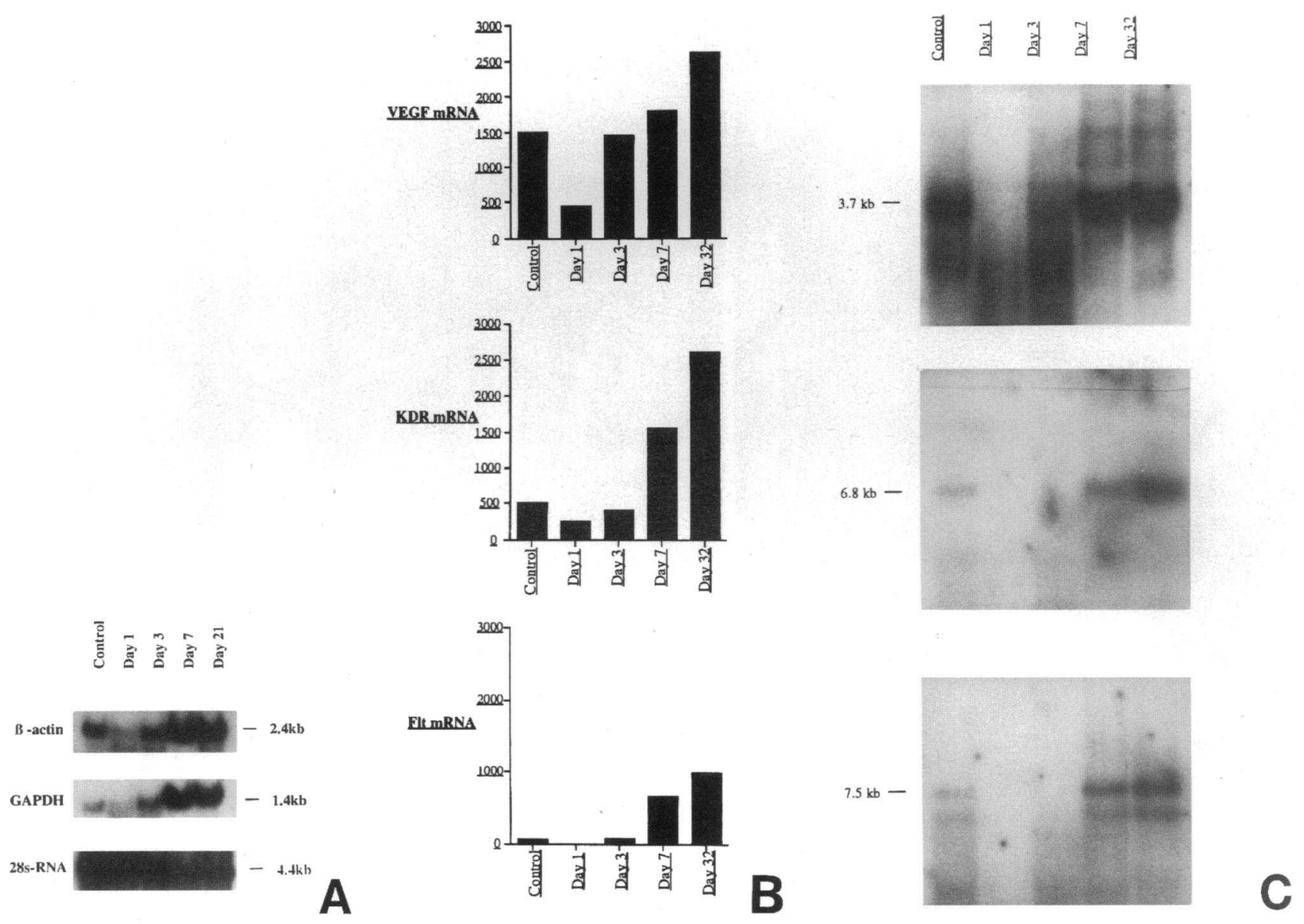

Figure 2. (A) Rat lung $\beta$-Actin and GADPH, but not a $28 \mathrm{~S}$ ribosomal gene expression increases during chronic hypoxia. $(B$ and $C$ ) Northern blot for VEGF, KDR/Flk, Flt mRNA. The bar graphs represent scanning densitometry of the hybridization products for the VEGF, KDR/Flk, and Flt signals $(B)$. 28S ribosomal RNA was used to control for RNA loading. Compared are samples from control (normoxic) and chronically hypoxic animals.

KDR/Flk and Flt hybridization signals when compared with perfused, room-air ventilated lungs (Fig. 7). These lungs were not subject to increased vascular shear stress since, in lungs perfused with a salt solution, hypoxic vasoconstriction is not maintained.

Effect of NO on VEGF Transcripts. Since endotoxin induces the synthesis of NO (29), we wondered whether the effect of endotoxin on lung VEGF gene expression could be related to NO. Isolated lungs were perfused and ventilated under normoxic or hypoxic conditions, and SNP or L-NAME was added to the perfusate. SNP $\left(10^{-4} \mathrm{M}\right)$ decreased VEGF and VEGF receptor mRNA levels in the isolated lungs (Fig. 7), whereas L-NAME, a nitric oxide synthase inhibitor, increased VEGF mRNA expression (Fig. 8).

\section{Discussion}

It has been appreciated for many years that chronic hypoxia leads to pulmonary hypertension and remodeling of pulmonary arteries $(1-3,30,31)$. Since the muscularization of the pulmonary precapillary vessels is a prominent feature in animal models of hypoxic pulmonary hypertension, traditionally hypoxic vasoconstriction and "work hypertrophy" of the constricted vascular smooth muscle cells have been used as concepts to explain the mechanism of vascular remodeling. However, evidence for vascular cell proliferation (as in Fig. 1) has been presented by many investigators $(1,30,31)$.

Recent data supports the concept that hypoxia-unaccompanied by shear stress - can alter the expression of genes encoding vascular cell growth and angiogenesis factors (32). For example, activated protein kinase C (PKC) and activated PKC acting synergistically with added insulin-like growth factor stimulate proliferation of cultured pulmonary smooth cells (33). Clearly, hypoxia increases VEGF mRNA in cultured tumor cells (15), and angiogenesis associated with necrotic hypoxic foci in tumors and with wound healing may share certain aspects with the chronic hypoxia-induced lung vessel remodeling (14). We recently reported increased VEGF transcripts in the lung from patients with primary (unexplained) pulmonary hypertension and localized both VEGF receptor transcripts and VEGF protein in the characteristic proliferated blood channels present in the plexiform lesions (34).

The major findings presented in this report are that the VEGF gene and also the genes encoding the VEGF receptors KDR/Flk and Flt were increasingly expressed during the development of pulmonary hypertension in rat lungs in the course of prolonged exposure to hypoxia. An important additional finding of our study is that VEGF mRNA in the lungs increased 

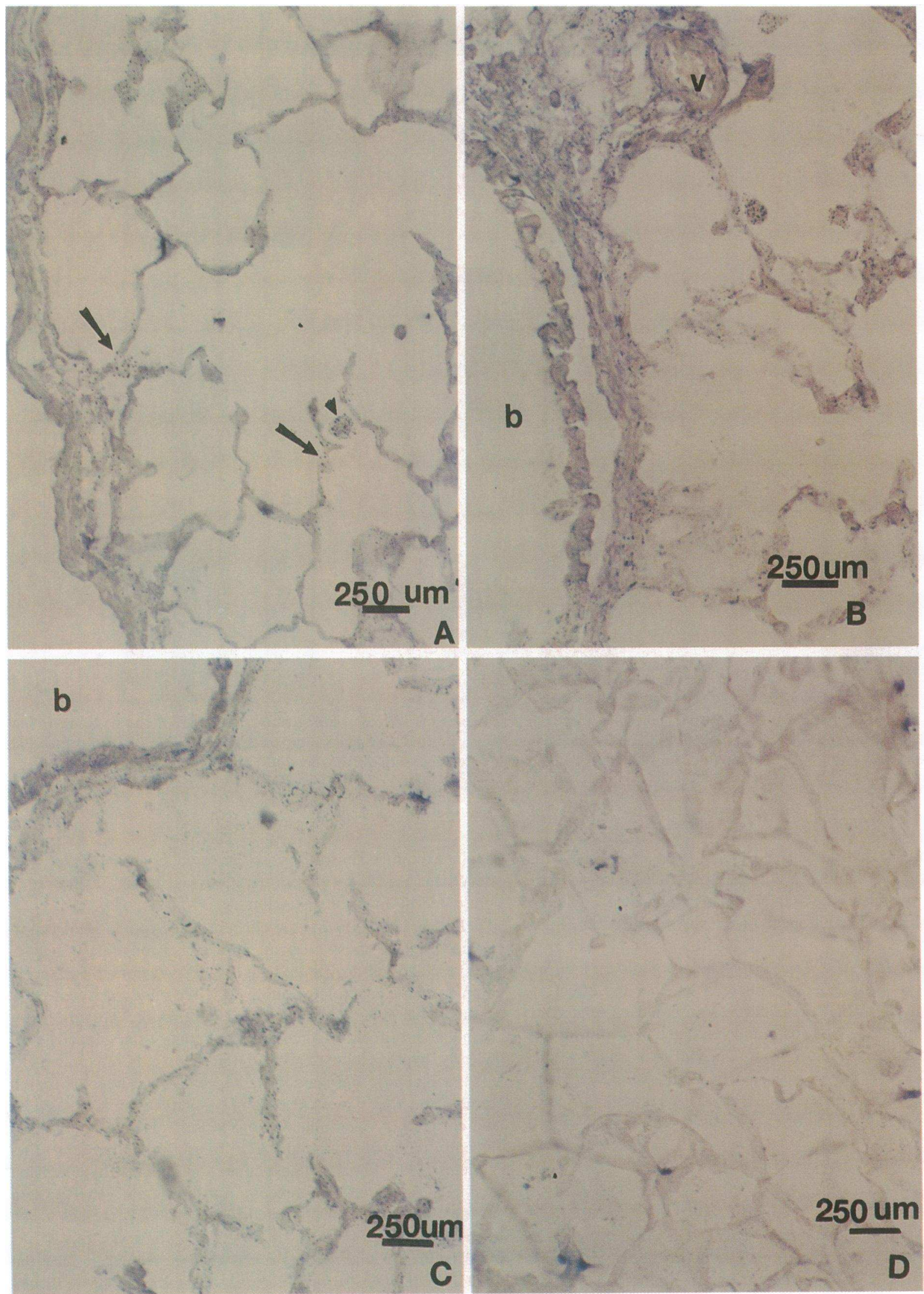

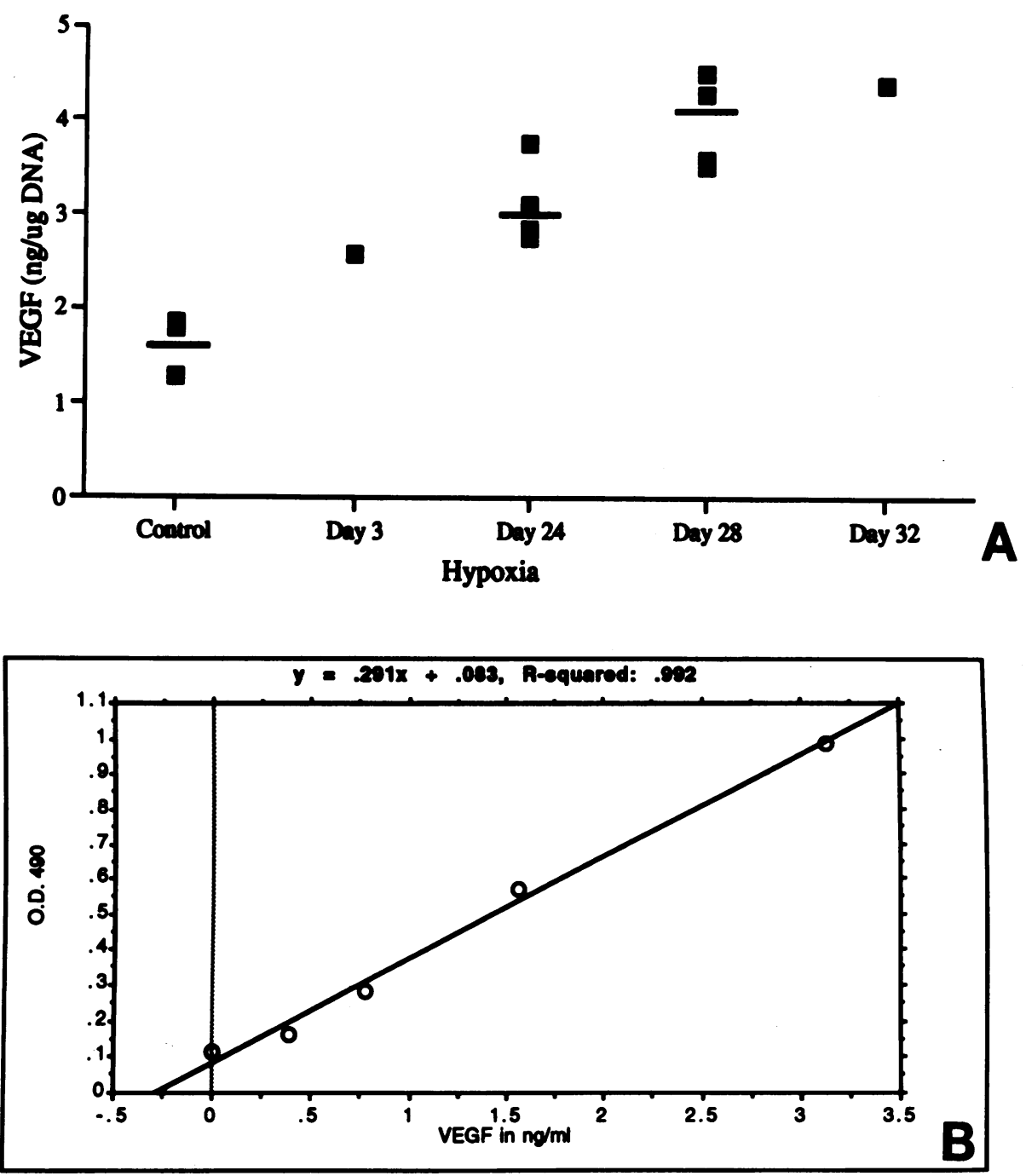

Figure 4. (A) Measurement of lung tissue VEGF by ELISA. (B) A standard curve was generated using known concentrations of VEGF.

within $2 \mathrm{~h}$ of hypoxia and further, that endotoxin and SNP decreased VEGF mRNA, indicating that VEGF gene expression is also modulated by NO. The potential effect of NO on growth factor gene expression was recently demonstrated by the NOinduced downregulation of platelet derived growth factor (PDGF-B) transcripts in cultured endothelial cells during hypoxia (32).

The increased VEGF gene expression during chronic hypoxia correlated with the levels of VEGF protein. Our in situ hybridization studies using lungs from control rats and from rats after progressively longer hypoxia exposures confirm the studies by Monacci et al. (10) who reported abundant VEGF transcripts in rat alveolar epithelial cells. However, in our study, at 28-32 d of chronic hypoxia, the VEGF transcript expression was increased in alveolar cells and, albeit to lesser degree, also in vascular smooth muscle cells and alveolar macrophages.

Perhaps of greater importance for the role of VEGF in the pathophysiology of vascular remodeling is the fact that, during chronic hypoxia, there is a parallel and even greater upregulation in the expression of the KDR/Flk and Flt transcripts in lungs from animals exposed to hypoxia for up to 28-32 d. Notably, short-term exposure of isolated lungs to hypoxia also increased the Flt and KDR/Flk mRNA. Whereas it has been reported that hypoxia is a strong stimulator of VEGF gene expression in cultured cells, it is a novel observation that chronic hypoxia increases gene expression of VEGF receptors. Shear stress may account for the upregulation of the VEGF receptor genes in the in vivo chronic hypoxia experiments since both

Figure 3. In situ hybridization for VEGF mRNA in lungs of rats exposed to hypoxia for 21 and for $28 \mathrm{~d}$. (A) Control lung: VEGF mRNA is expressed in cells of the alveolar septa (arrow) and in intraalveolar cells, possibly macrophages (arrowhead). (B) Day 21 of hypoxia: note the increase in VEGF mRNA signal as assessed semiquantitatively by an increase in fast blue grain-like deposits in both alveolar septal, intra-alveolar and bronchiolar cells $(b$, arrowhead). A small pulmonary vessel $(v)$ exhibits low levels of VEGF expression when compared with the parenchymal cells. (C) Day 28 of hypoxia: high VEGF transcript levels are seen in the same cellular compartments as seen in day 21 of hypoxia. D. Control VEGF in situ hybridization with sense VEGF cRNA probe. $(A-D)$ Digoxigenin-labeled probes, and immunoalkaline phosphatase; $\times 400)$. 

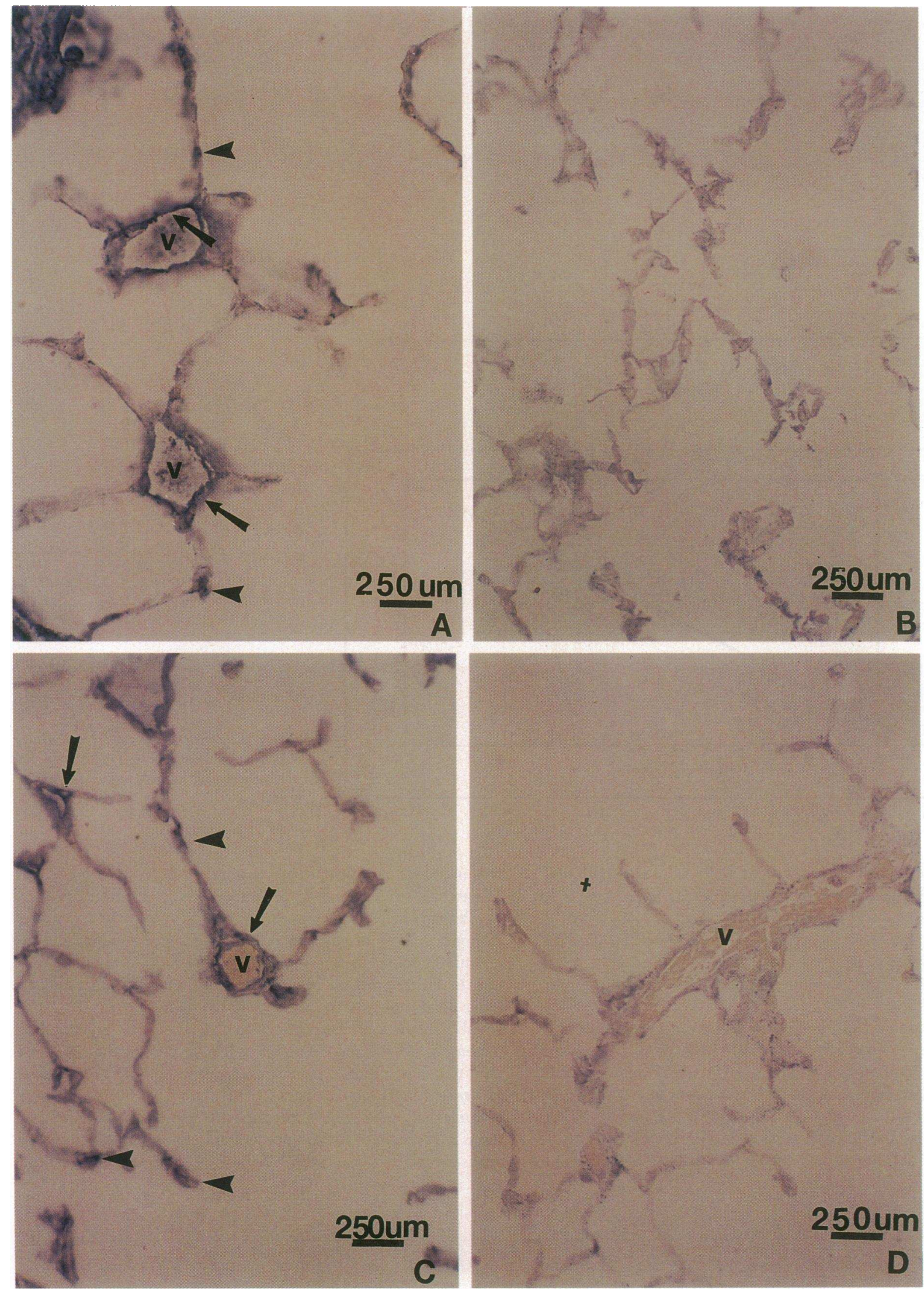

Figure 5. In situ hybridization for KDR/Flk mRNA in lungs of rats exposed to hypoxia for $7 \mathrm{~d}$. $(A)$ Control lung: the alveolar precapillary blood vessels $(v)$ exhibit KDR/Flk mRNA, mostly in the endothelial layer (arrows). Note weak signal in the alveolar capillaries (arrowhead). (B) Control sense KDR/Flk cRNA in normoxic lung. (C) Day 7 of hypoxia: KDR/Flk mRNA is present in multiple precapillary vessels, in a distribution similar to that seen in control animals. $(D)$ Sense KDR/Flk cRNA in day 7 hypoxic lung. $(A-D)$ Digoxigenin-labeled cRNA probes, and immunoalkaline phosphatase; $\times 400$ ). 

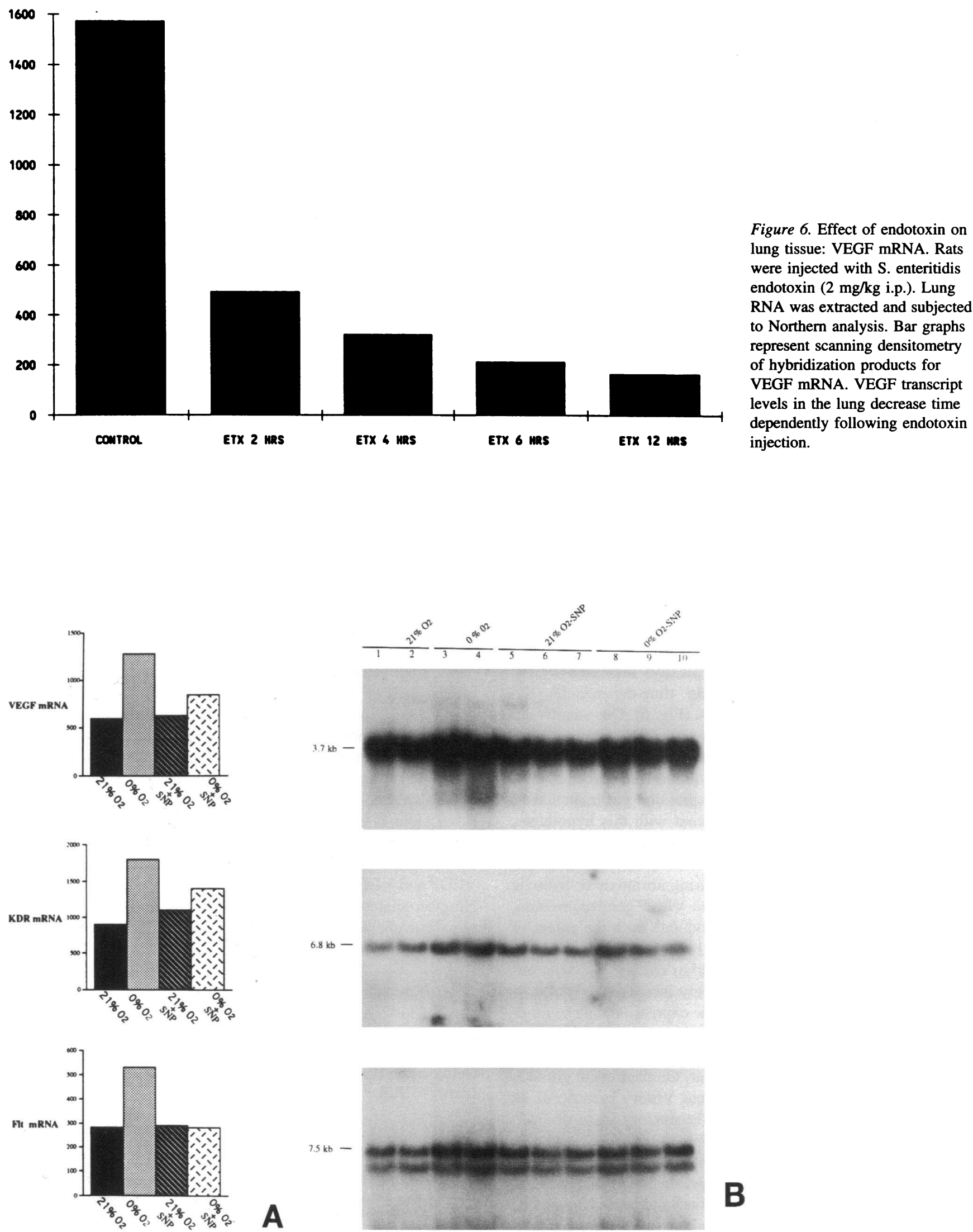

Figure 7. $(A$ and $B$ ) Effects of short term hypoxia effects on lung VEGF, KDR/Flk and Flt mRNA. Lungs were isolated and perfused with a cellfree salt solution and either ventilated with a normoxic $\left(21 \% \mathrm{O}_{2}, 5 \% \mathrm{CO}_{2}\right.$ balance $\left.\mathrm{N}_{2}\right)$ or a hypoxic gas mixture $\left(0 \% \mathrm{O}_{2}, 5 \% \mathrm{CO}_{2}\right.$ balance $\left.\mathrm{N}_{2}\right)$ for $2 \mathrm{~h}$. In some experiments, either SNP $\left(10^{-4} \mathrm{M}\right)$ or NAME $\left(10^{-4} \mathrm{M}\right)$ was added to perfusate. Each bar graph represents the mean of two or three independent experiments $(A)$. 


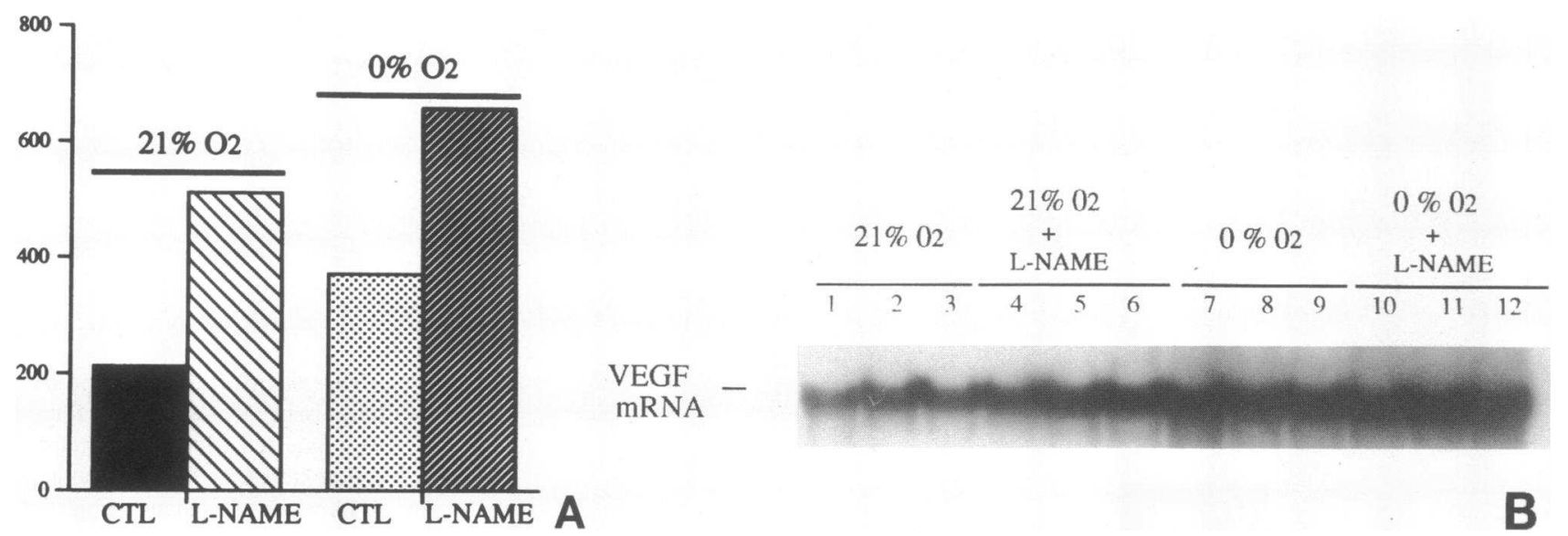

Figure 8. ( $A$ and $B)$ Effect of nitric oxide synthase inhibition on VEGF gene expression in isolated perfused lungs. Lungs were ventilated either with room air or under hypoxic conditions $\left(0 \% \mathrm{O}_{2}\right)$ for $2 \mathrm{~h}$ with and without L-NAME $(C T L)$ addition to the cell-free perfusate. The bar graphs represent the densitometric signals. Each bar represents the mean of three separate experiments.

KDR/Flk and Flt contain in their sequence the shear stress core element (5). This element is also present in the shear stress sensitive growth factors PDGF-B and TGF- $\beta$. However, in our acute hypoxic experiments, the isolated lungs were perfused at constant flow and pressure throughout the entire experimental period; since no agent was used to "prime"' the hypoxic pressor response, no hypoxic vasoconstriction and therefore no increase in shear stress occurred. Therefore we suggest that lung VEGF receptor gene expression can be modulated by hypoxia alone or by hypoxia and shear stress.

Hypoxia (either acutely or chronically) increased VEGF gene expression, whereas endotoxin time-dependently decreased the lung tissue VEGF mRNA (Fig. 6). Our studies did not address whether endotoxin suppresses VEGF transcription or decreases "message stability." Since endotoxin is a powerful activator of NO synthesis (29), we hypothesized that endotoxin decreased lung tissue VEGF gene expression via induction of NO synthesis in the lung. In agreement with this hypothesis, we found that the NO donor SNP inhibited the hypoxia-induced upregulation of lung VEGF gene expression. Moreover, inhibition of NO synthesis by L-NAME during normoxic or hypoxic ventilation of isolated lungs, increased VEGF gene expression. Endogenously produced NO may modulate both the extent of hypoxic vasoconstriction $(35,36)$ and also the VEGF synthesis in the normal lung. Furthermore, during chronic hypoxia, endogenous lung NO production is likely increased (37) and, if so, during chronic hypoxia VEGF gene expression may be modulated (downregulated) by such a NO dependent mechanism.

The role, if any, that VEGF plays in chronic pulmonary hypertensive states is presently unclear. On theoretical grounds one might be attracted to the idea that VEGF, because of its permeability/angiogenesis and pro-inflammatory properties (12) and because of its specificity for endothelial cells, might be involved in acute lung vascular injury and in endothelial cell proliferation. In severe pulmonary hypertension in man, particularly in the unexplained form of primary pulmonary hypertension, there is evidence for vigorous endothelial cell proliferation in the so-called plexiform and intimal concentric proliferative lesions (38). Both VEGF protein and transcripts are present in these lesions (34). We wondered whether VEGF could play a role in the pulmonary vascular remodeling in the chronic hyp- oxia rat model. We treated rats with suramin during chronic hypoxic exposure since suramin has been shown to block the interaction of VEGF with its receptors (39). Suramin decreased the degree of pulmonary hypertension and the development of right ventricular hypertrophy, without affecting lung VEGF mRNA and protein levels (40). One possibility is that the suramin-induced reduction in pulmonary hypertension was associated with inhibition of the VEGF-receptor interaction. More specific therapeutic strategies (including the use of anti-VEGF antibodies) will be required to test this hypothesis more rigorously since suramin also blocks the actions of other growth factors such as PDGF and fibroblast growth factor $(41,42)$.

In conclusion, both acute and chronic hypoxia increase lung tissue gene expression for VEGF and its receptors. Chronic hypoxia leads to increased synthesis (or decreased breakdown) of the VEGF protein. The fact that lung VEGF transcripts are increased after only $2 \mathrm{~h}$ of hypoxic challenge in isolated perfused lungs is consistent with the concept that VEGF behaves as an early gene. Its expression in the lung appears to be also under the control of NO or a NO-dependent metabolite. Whether VEGF and VEGF receptors are involved in the vascular remodeling associated with hypoxia-induced pulmonary hypertension remains to be seen.

\section{Acknowledgments}

The authors wish to thank Rebecca Kendig for her help in typing the manuscript and Mr. Thomas Bates and Kelly Wade for technical help. This work was supported by a Grant in Aid to Norbert F. Voelkel by the American Heart Association and by the Vascular Academic Award NIH K07 HLB.

\section{References}

1. Voelkel, N. F., U. Wiegers, V. Sill, and J. Trautmann. 1977. A kinetic study of lung DNA-synthesis during simulated chronic high-altitude hypoxia. Thorax. 32:578-581.

2. Niedenzu, C., K. Grasedyck, N. F. Voelkel, S. Bittman, and J. Lindner. 1981. Proliferation of lung cells in chronically hypoxic rats. Int. Arch. Occup. Environ. Health. 4:185-193.

3. Rabinovitch, M., W. Gamble, A. S. Nades, O. S. Miettinen, and L. Reid. 1979. Rat pulmonary circulation after chronic hypoxia: hemodynamics and structural features. Am. J. Physiol. 236:H818-H827. 
4. Dempsey, E. C., I. F. McMurtry, and R. F. O’Brien. 1989. Protein kinase $\mathrm{C}$ activation allows bovine pulmonary artery smooth muscle cells to proliferate in response to hypoxia. Am. Rev. Respir. Dis. 139:A171.

5. Resnick, N., T. Collins, W. Atkinson, D. T. Bonthron, C. Forbes Dewey Jr., and M. A. Gimbrone, Jr. 1993. Platelet-derived growth factor B chain promoter contains a cis-acting fluid shear-stress-responsive element. Proc. Natl. Acad. Sci. USA. 90:4591-4595.

6. Senger, D. R., S. J. Galli, A. M. Dvorak, C. A. Perruzzi, V. S. Harvey, and H. F. Dvorak. 1983. Tumor cells secrete a vascular permeability factor that promotes accumulation of ascites fluid. Science (Wash. DC). 219:983-985.

7. Ferrara, N., and W. J. Henzel. 1989. Pituitary follicular cells secrete a novel heparin-binding growth factor specific for vascular endothelial cells. Biochem. Biophys. Res. Commun. 161:851-858.

8. Berse, B., L. F. Brown, L. van de Water, H. F. Dvorak, and D. R. Senger. 1992. Vascular permeability factor (vascular endothelial growth factor) gene is expressed differentially in normal tissues, macrophages and tumors. Mol. Biol. Cell. 3:211-220.

9. Shweiki, D., A. Itin, G. Neufeld, H. Gitay-Goren, and E. Keshet. 1993. Patterns of expression of vascular endothelial growth factor (VEGF) and VEGF receptors in mice suggest a role in hormonally regulated angiogenesis. J. Clin. Invest. 91:2235-2243

10. Monacci, W. T., M. J. Merrill, and E. H. Oldfield. 1993. Expression of vascular permeability factor/vascular endothelial growth factor in normal rat tissues. Am. J. Physiol. 264:C994-C1002.

11. Breier, B., U. Albrecht, S. Sterrer, and W. Risau. 1992. Expression of vascular endothelial growth factor during embryonic angiogenesis and endothelial cell differentiation. Development (Camb.). 114:521-532.

12. Clauss, M., M. Gerlach, H. Gerlach, J. Brett, F. Wang, P. C. Familletti, Y.-C. E. Pan, J. V. Olander, D. T. Connolly, and D. Stern. 1990. Vascular permeability factor: a tumor-derived polypeptide that induces endothelial cell and monocyte procoagulant activity, and promotes monocyte migration. J. Exp. Med. 172:1535-1545.

13. Connolly, D. T., J. V. Olander, D. Heuvelman, R. Nelson, R. Monsell, N. Siegel, B. L. Haymore, R. Leimgruber, and J. Feder. 1989. Human vascular permeability factor. J. Biol. Chem. 264:20017-20024.

14. Senger, D. R., L. Van De Water, L. F. Brown, J. A. Nagy, K.-T. Yeo, T.-K. Yeo, B. Berse, R. W. Jackman, A. M. Dvorak, and H. F. Dvorak, H.F. 1993. Vascular permeability factor (VPF, VEGF) in tumor biology. Cancer Metastasis Rev. 12:303-324

15. Shweiki, D., A. Itin, D. Soffer, and E. Keshet. 1992. Vascular endothelial growth factor induced by hypoxia may mediate hypoxia-initiated angiogenesis. Nature (Lond.). 359:843-845.

16. Terman, B. I., M. E. Carrion, E. Kovacs, B. A. Rasmussen, R. L. Eddy, and T. B. Shows. 1991. Identification of a new endothelial cell growth factor receptor tyrosine kinases. Oncogene. 6:1677-1683.

17. Terman, B. I., M. Dougher-Vermazen, M. E. Carrion, D. Dimitrov, D. C. Armellino, D. Gospodarowicz, and P. Bohlen. 1992. Identification of the KDR tyrosine kinase as a receptor for vascular endothelial cell growth factor. Biochem. Biophys. Res. Commun. 187:1579-1586.

18. Quinn, T. P., K. G. Peters, C. De Vries, N. Ferrara, and L. T. Williams. 1993. Fetal liver kinase 1 is a receptor for vascular endothelial growth factor and is selectively expressed in vascular endothelium. Proc. Natl. Acad. Sci. USA. 90:7533-7537.

19. Shibuya, M., S. Yamaguchi, A. Yamane, T. Ikeda, A. Tojo, H. Matushime, and M. Sato. 1990. Nucleotide sequence and expression of a novel human receptor-type tyrosine kinase gene $(f t)$ closely related to the $f m s$ family. Oncogene. 5:519-524

20. De Vries, C., J. A. Escobedo, H. Ueno, H., K. Houck, N. Ferrara, and L. T. Williams. 1991. The fms-like tyrosine kinase, a receptor for vascular endothelial growth factor. Science (Wash. DC). 255:989-991.

21. Waltenberger, J., L. Claesson-Welsh, A. Siegbahn, and C.-H. Heldin. 1994. Functional comparison of KDR and Flt receptors for the vascular endothelial growth factor. J. Cell Biochem. Suppl. 18A:322.

22. Millauer, B., L. K. Shawver, K. H. Plate, W. Risau, and A. Ulrich, A.
1994. Glioblastoma growth inhibited in vivo by dominant-negative Flk-1 mutant. Nature (Lond.). 367:576.

23. Halbower, A. C., R. J. Mason, S. H. Abman, and R. M. Tuder. 1994 Agarose infiltration improves morphology of cryostat sections of lung. Lab. Invest. 71:149-153

24. Ono, S., J. Y. Westcott, and N. F. Voelkel. 1992. PAF antagonists inhibit pulmonary vascular remodeling induced by hypobaric hypoxia in rats. $J$. Appl. Physiol. 73:1084-1092.

25. Chomcynski, P., and N. Sacchi. 1987. Single-step method of RNA isolation by acid guanidinium-thiocyanate phenol chloroform extraction. Anal. Biochem. 162:156-159.

26. Webster, K. A., P. Gunning, E. Hardeman, D. C. Wallace, and L. Kedes. 1990. Coordinate reciptrocal trends in glycolytic and mitochondrial transcrip accumulations during the in vitro differentiation of human myoblasts. J. Cell. Physiol. 142:566-573.

27. Kletzien, R. F., P. K. Harris, and L. A. Foellmi. 1994. Glucose-6-phosphate dehydrogenase: a "housekeeping" enzyme subject to tissue-specific regulation by 7-21 hormones, nutrients, and oxidant stress. FASEB (Fed. Am. Soc. Exp. Biol.) J. 8:174-181.

28. Reid, L. M., and P. Davies. 1989. Control of cell proliferation in pulmonary hypertension. In Pulmonary Vascular Physiology and Pathophysiology. E. K. Weir, and J. T. Reeves, editors. Marcel Dekker, New York. 541-611.

29. Kilbourn, R. G., and P. Belloni. 1990. Endothelial cells produce nitrogen oxides in response to interferon- $\gamma$, tumor necrosis factor and endotoxin. In Nitric Oxide from L-Arginine: A Bioregulatory System. S. Moncada, and E. A. Higgs, editors. 61-67

30. Meyrick, B. O., and L. Reid. 1987. The effect of continued hypoxia on rat pulmonary arterial circulation: an ultrastructural study. Lab. Invest. 38:188200

31. Jones, R. C. 1993. Role of interstitial fibroblasts and intermediate cells in microvascular wall remodelling in pulmonary hypertension. Eur. Respir. Rev. 3:569-575.

32. Kourembanas, S., L. P. McQuillan, G. K. Leung, and D. V. Faller. 1993 Nitric oxide regulates the expression of vasoconstrictors and growth factors by vascular endothelium under both normoxia and hypoxia. J. Clin. Invest. 92:99104

33. Dempsey, E.C., K. R. Stenmark, I. F. McMutry, R. F. O’Brien, N. F. Voelkel, and D.B. Badesch. 1990. Insulin-Like growth factor I and protein kinase $\mathrm{C}$ activation stimulate pulmonary artery smooth muscle cell proliferation through separate but synergistic pathways. J. Cell. Physiol. 144:159-165.

34. Tuder, R. M., D. B. Badesch, B. Groves, D. A. Lynch, and N. F. Voelkel. 1994. Vascular endothelial permeability/growth factor expression in plexogenic pulmonary hypertension. J. Cell. Biochem. Suppl 18A:330.

35. Hasunuma, K., T. Yamaguchi, D. M. Rodman, R. F. O'Brien, and I. F McMurtry. 1991. Effects of inhibitors of EDRF and EDHF on vasoreactivity of perfused rat lungs. Am. J. Physiol. 260:L97-L104.

36. Eddahibi, S., S. Adnot, Cl Carville, Y. Blouquit, and B. Raffestin. 1992 L-arginine restores endothelium-dependent relaxation in pulmonary circulation of chronically hypoxic rats. Am. J. Physiol. 263:L194-L200.

37. Barer, G., C. Emery, A. Stewart, D. Bee, and P. Howard. 1993. Endothelial control of the pulmonary circulation in normal and chronically hypoxic rats. $J$. Physiol. 463:1-16.

38. Tuder, R. M., B. Groves, D. B. Badesch, and N. F. Voelkel. 1994. Exuberant endothelial cell growth and elements of inflammation are present in plexiform lesions of pulmonary hypertension. Am. J. Pathol. 144:275-285.

39. Vaisman, N., D. Gospodarowicz, and G. Neufeld. 1990. Characterization of the receptors for vascular endothelial growth factor. J. Biol. Chem. 265:19461 19466

40. Voelkel, N. F., M. A. Voelkel, and B. Flook, B. 1993. Suramin inhibits monocrotaline (MCT)-induced pulmonary hypertension in rats. Circulation. Suppl 88:I-285. (Abstr.)

41. Pesenti, E., F. Sola, N. Mongelli, M. Grandi, and F. Spreafico. 1992. Suramin prevents neovascularisation and tumour growth through blocking of basic fibroblast growth factor activity. Br. J. Cancer. 66:367-372.

42. Hosang, M. 1985. Suramin binds to platelet-derived growth factor and inhibits its biological activity. J. Cell. Biochem. 29:265-273. 